\title{
3 種アザミウマ類に対するミヤコカブリダニの捕食能力
}

\author{
溝辺 真 ${ }^{11} \cdot$ 柏尾 具俊 ${ }^{21} \cdot$ 森田 茂樹 ${ }^{31} \cdot$ 高木 正見 ${ }^{31}$ \\ (1)宮崎県総合農業試験場・21 九州沖䋥農業研究センター野菜花き研究部・31 九州大学農学研究院)
}

\begin{abstract}
Predation rate of Neoseiulus californicus (McGregor) on three species of greenhouse thrips. Makoto Mizobe" ${ }^{1}$. Tomotoshi Kashio ${ }^{23}$ Shigeki Morita ${ }^{3 \prime}$ and Masami Takagi ${ }^{37}$ ("Miyazaki Agricultural Experiment Station, Sadowara, Miyazaki 880-0212. Japan." National Agricultual Research Center for Kyushu Okinawa Region, Kurume, Fukuoka 839 - 8503, Japan. ${ }^{3)}$ Faculty of Agriculture and Graduate School of Bioresource and Bioenvironmental Sciences Kyushu University. Fukuoka 812-8581, Japan)
\end{abstract}

We studied the feeding ability and functional response of adult females of the predatory mite Neoseiulus californicus (McGregor) on greenhouse thrips. The females could attack 1 st instar larvae of Frankliniella occidentalis, but not 2 nd instar larvae, pupae, or adult females. The numbers of 1 st instar larvae of F.occidentalis, Thrips palmi, and Frankliniella intonsa consumed by the predatory mite increased as the prey density increased. The mean maximum predation rates per day against 1 st instar larvae were 7.1 Foccidentalis, 6.9 T.palmi and 3.1 F.intonsa. These result suggest that $N$. californicus is an effective natural enemy of these thrips.

Key words : Frankliniella intonsa, Frankliniella occidentalis, Neoseiulus californicus, predatory ability, predatory mite, Thrips palmi

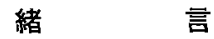

ミヤコカブリダニNeoseiulus californicus (McGregor) はカリフォルニアや地中海地方などに広く分布するほか, 日本にも分布する捕食性カブリダニである。本種は施設 野菜の重要害虫であるナミハダニTetranychus urticae (Koch) などハダニ類の天敵として2003年に農薬登録さ れ，その利用拡大が期待されている（意木，2004）。一 方，ハダ二類の天敵としては, チリカブリダニ Phytoseiulus persimilis (Athias-Henriot) が生物農薬と してすでに市販さ狄ており，优成栽培のイチゴなどでは 実用的利用が始まっている（訔本，2003）。そのため， ミヤコカブリダニの效果的な利用をはかるには、本種と チリカブリダニをどのように使い分けていくかが間題と なる。

ミヤコカブリダニとチリカブリダニのハダニ類に対す る捕食能力や制御能力を直接比較した事例は少ないが, ミヤコカブリダニはチリカブリダニに比べてナミハダニ 卵に対する捕食能力がやや少るという報告がある (Fiese and Gilstrap, 1982)。また，イチゴのカンザワ ハダニに対するこれら 2 種カプリダニの制御効果を比較 すると、ミヤコカブリダニはハダ二類を抑制するまでの
日数がチリカブリダニに比べてやや長い（高田・柏尾， 2004)。したがって，八ダ二類に対する制御能力の点か らみると、ミヤコカブリダニをチリカブリダニに代わる 生物資材として利用することは難しいと考えられる。

しかし、チリカブリダニがハダ二科の中でも主に Tetranychus 属を捕食する（森・真梶，1974）のに対し, ミヤコカブリダニはハダニ類のほかチヤノホコリダニ Polyphagotarsonemus latus (Banks) やニセナシサビダ 二Eriophyes chibaensis (Kadono) なども捕食し（天野, 2004），㕕食性であるという特性を持つ。また：ミヤコ カブリダニはチリカブリダニでは発育障害がみられる $32.5^{\circ} \mathrm{C}$ P $35^{\circ} \mathrm{C}$ 高温条件でも正常に発育し, 捕食量の低 下も認められないことから，チリカブリダニより高温に 適しているよ考えられている（梅津ら，2000)。このよ うな特性からみて，本種はハダ二類以外の害虫に対する 同時防除効果も衫らう必要がある場面や高温期の利用に おいてチリカブリダニより効果的な利用が可能と考えら れる。

一方、ミヤコカブリダニが属するムチカブリダニ亜科 のカブリダニ類の中には，アザミウマ類を飭としている 種が含まれており，クタメリスカブリダニAmblyseius cucumeris (Oudeman) やデジェネランスカブリダニ 
Amblyseius degenerans (Berlese) のようにアザミウマ 類を対象とした生物農薬として市販されているものがあ る。また，クワアザミウマPseudodendrothrips mori (Niwa) を捕食するニセラーゴカブリダニAmblyseius eharai (Amitai et Swirski)（杮元ら，2004）やチャノキ イロアザミウマScirtothrips dorsalis（Hood）を捕食す るコウッ゙ケカブリダニAmblyseius sojaensis（Ehara） (Shibao et al.. 2002) などの土着天敵も，アザミウマ類 を飭とすることが報告されている。したがって，広食性 とされるミヤコカブリダニについてもア+゙ミウマ類を䬣 としている可能性があるが，本種がアザミウマ類を飭と しているとの報告はない。

そこで本研究では, ミカンキイロアザミウマ Frankliniella occidentalis (Pergande) の各発育ステー ジに対するミヤコカブリダニの捕食能力を調查した。さ らに，施設野菜の重要害虫であるミカンキイロアザミウ マとヒラズハナアザミウマFrankliniella intonsa (Trybom)，ミナミキイロアザミウマThrips palmi (Karny）の各 1 齢幼虫を対象に：ミヤコカブリダニの 機能の反応を調查した。

なお，本研究を行うにあたり、ミヤコカブリダ二（商 品名：「スパイカル」）を提供していただいたアリスタラ イフサイエンス株式会社に厚くお礼申し上げる。また， この試験は宮崎県の研修予算により，九州沖縄農業研究 センター野菜花き研究部において実施したものであり， 研修の機会を与えて下さった宮崎県総合農業試騒場生物 環境部の田村逸美部長をはじめ，研修の設定にご努力頂 いた関係各位に対して厚く御礼申し上げる。

\section{材料および方法}

\section{1. 供試虫}

ミヤコカブリダニ(商品名：「スパイカル」,アリスタ ライフサイェンス株式会社）は，インゲン豆で増殖した ナミハダニを䬣として室内で累代飼命し，実験に用いた。

ミカンキイロアザミウマとヒラズハナアザミウマは, 九州沖縄農業研究センター野菜花き研究部においてマツ の花粉を用いて累代飼育している個体群を供試した。ミ ナミキイロアザミウマは, 九州大学農学部生物的防除研 究施設から分譲された個体群をインゲン豆の幼苗を用い て増殖し，奏験に供した。

\section{2. ミカンキイロアザミウマの各発育ステージに対す る捕食量}

実験は，ミカンキイロアザミウマの 1 龄幼虫， 2 齢幼 虫, 第 2 蛹, 雌成虫を対象として行った。1 龄幼虫につ いては，ふ化直後の個体とインゲン葉上で 24 時間飼育後
の個体では体サイズに大きな違いがみられた。このため， 湿らせたろ紙上においた卵から24時間以内にふ化した個 体（体長約 $0.5 \mathrm{~mm}$; 以下，「1 龄前期幼虫」とする）と インゲン葉の上で 24 時間飼青後の個体（体長約 $0.6 \mathrm{~mm}$; 以下，「1㱓後期幼虫」とする）に分けて実験を行った。 ミカンキイロアザミウマの 2 齢幼虫, 第 2 蛹, 雌成虫に ついては，ふ化幼虫をマッの花粉で飼育した個体を用い た。

直径 $3 \mathrm{~cm}$ の穴を中央に 1 つ開けたアタリル製の飼育 ケージ（高田・柏尾，2004）の底にインゲン葉を敷き, その上にミカンキイロアザミウマを発育ステージ別に小 筆を用いて入れた。ケージ内のアザミウマ密度は 1 齢萠 期幼虫, 1 齢後期幼虫, 2 歯幼虫の場合は 16 頭, 第 2 蛹, 成虫の場合は12頭とした。これらの飼育ケージに,ナミ ハダニを飭として飼青した羽化 3 〜日後の交尾済みの ミヤコカブリダニ雌成虫 1 頭を放飼した。また，本種の 捕食によらないアザミウマ幼虫の死亡数を知るため、ア ザミウマの発䏍ステージ別にカブリダニを放飼しない区

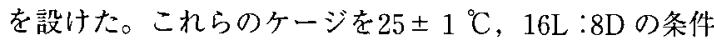
に設定した恒温器内に置き，24時間後に実体顕微鏡下で アザミウマの死亡数を調查し，捕食による死し数を算出 した。試験はいずれも10反復行った。

\section{3 種アザミウマ類幼虫に対する慨密度と捕食量の 関係}

奏験はミカンキイロアザミウマ，ヒラズハナアザミウ マ，ミナミキイロアザミウマを対象とし，いずれもふ化 後24時間以内の 1 龄前期幼虫を供試した。上記と同様の 飼育ケージ内に，アザミウマ約虫を $1 ， 2 ， 4 ， 8 ， 16$, 拉よび32頭ずつ小筆を用いて入れ，さらに羽化 $3 \sim 5$ 日 後の既交尾のミヤコカブリダ二雌成虫 1 頭を放飼した。 これらのケージを $25 \pm 1{ }^{\circ} \mathrm{C} ， 16 \mathrm{~L}: 8 \mathrm{D} の$ 条件下に置き, 24時間後に实体顕微鏡下でアザミウマ幼虫の死亡数を調 查した。各䬣密度ともに15反復の試験を行った。なお, この実験でもカブリダ二を放飼しない区を設け，アザミ ウマ幼虫の死亡数を調べた。

また,これらの結果を Holling（1959）の円盤方程式 $y=a T x /(1+a b x)$

にあてはめた。

ここで， $y$ は捕食量， $x$ は餌密度， $T$ は時間， $a$ は発見 面積， $b$ は処理時間であり，伊藤・村井（1977）を参考 に最小自乗法により，発見面積（a）と処理時間（b) を求めた。

結果

ミカンキイロアザミウマの各発育ステージに対するミ 
ヤコカブリダニ雌成虫の捕食量をTable 1 に示した。ミ ヤコカブリダニ雌成虫はミカンキイロアザミウマの 1 歯 幼虫を飭とした場合には捕食活動が認められ，24時間当 たりの捕食量は 1 齢前期幼虫では7.3頭, 1 龄後期幼虫 では4.1頭であった。一方，2齢幼虫，第 2 蛹，倠成虫 を䬣とした場合は捕食された個体は認められなかった。 なお，ミヤコカブリダニを放飼しない区については，い ず扎のステージでも死亡個体はみられなかったため，力 ブリダニ放飼区の死亡個体はすべて捕食されたものと判 断した。

ミカンキイロアザミウマ, ヒラズハナアザミウマ, ミ ナミキイロアザミウマの 1 觝前期幼虫を慨とした場合の 慨密度とミヤコカブリダニ雌成虫の捕食量との関係を Fig.1に示した。ミヤコカブリダニによるアザミウマ幼 虫に対する 1 雌当たりの平均捕食量は，いずれのアザミ ウマの場合も餌密度が高くなるにつれて増加する傾向を 示し，䬣密度が16頭のときに最大となった。最大捕食量 (/日/雌) は，ミカンキイロアザミウマでは7.1士0.6頭, ミナミキイロアザミウマでは $6.9 \pm 1.3$ 頭, ヒラズハナア

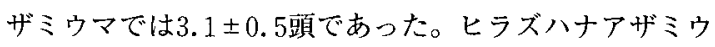
マに対する最大捕食量とミカンキイロアザミウマあるい はミナミキイロアザミウマに対する最大捕食量との間に は有意な差がみられた（Tukey法， $P<0.05 ） 。 な お ，$ この実験においても，ミヤコカブリダニを放飼しない区 では死し個体はみられなかったので，カブリダニ放飼区 の死し個体はすべて捕食されたものと判断した。

また, Hollingの円盤方程式によって発見面積 (a) と 処理時間（b) を求めたところ，処理特間 (b) はミカ ンキイロアザミウマの值が最も低く, 次に低かったのは ミナミキイロアザミウマであった。一カ，発見面積はミ カンキイロアザミウマの值が最も高く，次に高かったの はヒラズハナアザミウマであった（Fig. 1)。

\section{考察}

捕食性ダニ類の中には，ミナミキイロアザミウマやミ カンキイロアザミウマの有力な天敵として実用的に利用 されているククメリスカブリダニやデジェネランスカブ リダニなどをはじめ，アザミウマ類を捕食する種が知ら れている。これらの捕食性ダニ類の捕食能力についてみ ると、ククメリスカブリダニのミカンキイロアザミウマ 1 齢幼虫に対する捕食量は慨密度が20頭のとき約 5 頭／ 日，40頭のとき約 7 頭/日である（Shipp and Whitfield， 1991)。また, Houten et al. (1995) は, ミカンキイロア

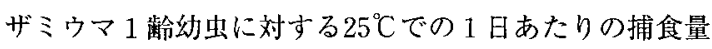
をククメリスカブリダニの場合 6.0 頭, デジェネランス
Table 1. Predation rate of Neoseiulus californicus on different developmental stages of Frankliniella occidentalis at $25 \pm 1{ }^{\circ} \mathrm{C}$

\begin{tabular}{lc}
\hline \multicolumn{1}{c}{ Developmental stage of prey } & No. of prey attacked per $24 \mathrm{~h}( \pm \mathrm{SE})$ \\
\hline 1st instar larvae & $7.3 \pm 0.8$ \\
1st instar larvae & \\
2nd instar larvae & $4.1 \pm 0.5$ \\
pupae & 0.0 \\
Adult female & 0.0 \\
\hline
\end{tabular}

a) 0 to $24 \mathrm{~h}$ old. b) 24 to $48 \mathrm{~h}$ old.

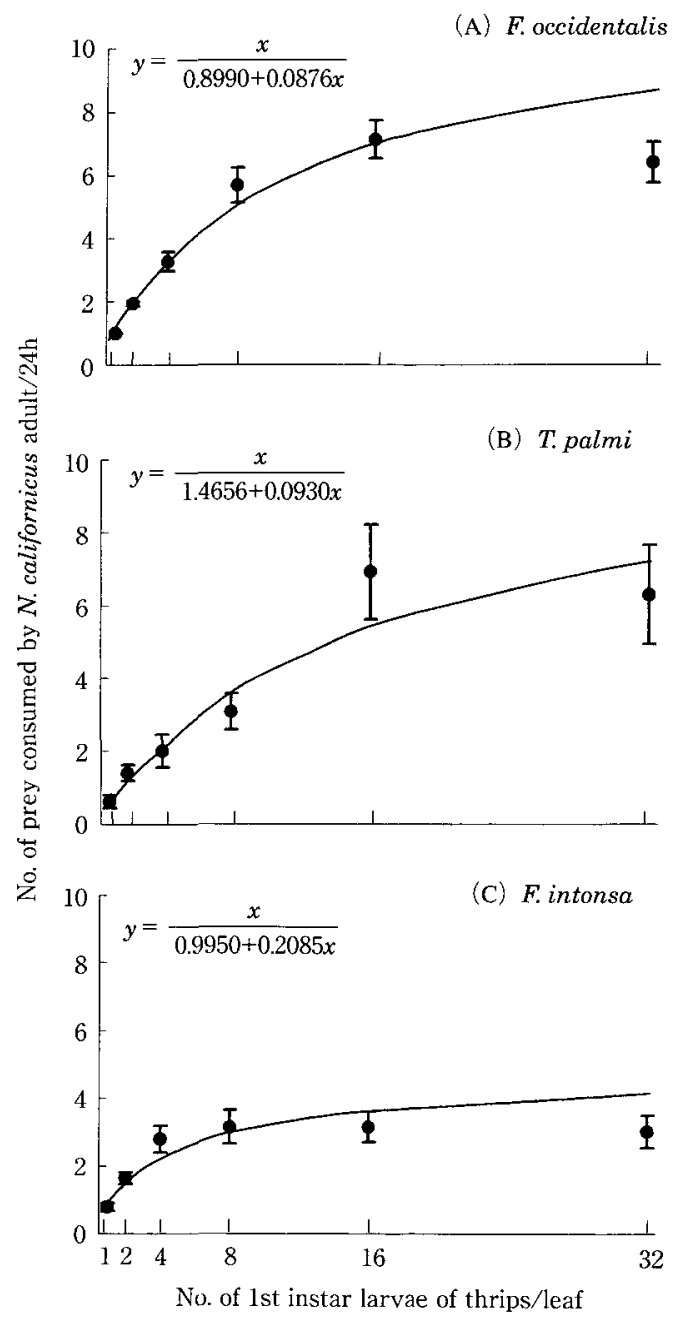

Fig. 1. Functional responses of Neoseiulus californicus to the density of 1 st instar larvae of the three prey species at $25 \pm 1{ }^{\circ} \mathrm{C}$. (A) Frankliniella occidentalis $a$ (rate of successful search) $=1.1123, b$ (handling time) $=0.876$. (B) Thrips palmi $a=0.6823$, $b=0.0930$. (C) Frankliniella intonsa $a=1.0050$. $b=0.2085$. Dots and vertical bars indicate mean and standard errors. First instar larvae that hatched within $24 \mathrm{~h}$ were used for these experiments. 
カブリダニの場合4.4頭と報告している。本試験で得ら れたミヤコカブリダニによるミカンキイロアザミウマの 捕食量は，慨密度が16頭の条件で 1 齿前前期幼虫では7.3 頭，1齢後期幼出では4.1頭であった（Table 1)。した がって，ミヤコカブリダニはミカンキイロアザミウマの 1 龄幼虫に対してククメリスカブリダニやデジェネラン スカブリダニとほほ同等の捕食能力を持つと考えられる。 また、ミカンキイロアザミウマを䬣とした場合にミヤコ カブリダニによる発見面皘（a）が最も高く，処理時間 （b）が最も低かった（Fig.1）ことから，飭として用い た 3 種の中でミカンキイロアザミウマを最も効率的に捕 食したと考えられる。

ミナミキイロアザミウマに対する捕食能力ついては， ククメリスカブリダニの㭃虫捕食量が48時問あたり 7,8 頭であるという報告（足立，2001）や，ニセラーゴカブ リダニ雌成虫の 2 羚幼虫に対する捕食量が24時間あたり 7.8頭であるという報告がある（林元ら，2004）。こ机ら の報告亡本試験では，幼虫の発育ステージが異なるため 直接比較はできないものの，ミヤコカブリダニはミナミ キイロアザミウマに対して，これらの值に少らない捕食 量を示した (Fig.1)。

一方，ヒラズハナアザミウマに対する捕食量は，ミカ ンキイロアザミウマやミナミキイロアザミウマに比べて 少なく、約 $1 / 2$ であった。また，ヒラズハナアザミウ マに対するミヤコカブリダニの处理時間（b）は3種の 中で最も長くなった。これらのことから，ヒラズハナア ザミウマに対する捕食量が少ない理由の一因として，ア ザミウマ幼虫の捕食性ダニに対する防御行動が考えられ る。一般にアザミウマの幼虫は，捕食性ダニの攻揧を受 けると腹部を強く振って捕食性ダ二を追い払うことが知 ら机ている (Lewis, 1973 ; Malais, 1995)。こうした行動 は，ミカンキイロアザミウマ，ヒラズハナアザミウマの いずれに扔いても認められたが，飼育中のヒラズハナア ザミウマはミカンキイロアザミウマに比べて，集団を形 成する性質が強い傾向がみられた。したがって，このよ うな防御行動を集団で行うことで効果が高まり、ミヤコ カブリダニによる捕食行動を阻害した可能性も考えられ る。また，アザミウマの種によっては，腹部末端から刺 激性のある臭い物質を分泌し，捕食者の攻擊を回避する ことが知られている (Maliis and Ravensberg, 1995)。 ヒラズハナアザミウマの場合，このような防御物質を分 泌するかどうかについては不明であり，今镜の解明が望 まれる。

本実験では，ミカンキイロアザミウマの 2 齢㭃虫，第 2 蛹，雌成虫に対して捕食はみられなかった。しかし，
これらのステージを慨とした場合にも，ミヤコカブリダ ニがアザミウマに近简り，脚を捕捉しょうとする行動が 時折観祭された。したがって、ミヤコカブリダニは 2 齢 幼虫などに対しても捕食行動を取るが，捕食が成功する ことはほとんどないと考えられる。さらに，体のサイズ が小さい 1 齢前期幼虫に対する捕食量が 1 齢後期幼虫に 対する捕食量の約 2 倍となったのもこの防御行動の強 さが一因となっていると考えられる。

以上のように，ミヤコカブリダニはミカンキイロアザ ミウマやミナミキイロアザミウマを䬣として利用し，そ の捕食能力はアザミウマ類の生物農薬として実用化され ているククメリスカブリダニと比べても劣らないことが わかった。したがって，本種はハダ二類のほか，アザミ ウマ類の防除にも利用できる生物資材としての利用が期 待される。八ダニ類とアザミウマ類はいずれも施設野菜 の重要害虫であり，イチゴ，ナス，メロンのように，こ れら 2 種が同時に発生する作物も多く，本種を利用でき る場面も数多いと考えら机る。しかし，本実験で得られ た結果は室内条件におけるものであり，本種を効果的に 利用するには，本種の作物上に扔けるハダニ類とアザミ ウマ類に対する制御能力や戒場に拀ける定着性等につい てさらに詳細な検討が必要である。

\section{摘要}

八ダニ類の生物農薬であるミヤコカブリダニ呲成虫の ミカンキイロアザミウマに対する捕食量を慨ステージ毎 に調查した。ミヤコカブリダニ雌成虫はミカンキイロア ザミウマの1龄幼出を捕食したが，2龄幼虫，第 2 虾， 成虫は捕食しなかった。1 羚幼虫に対する1日あたりの 捕食量は 1 龄前期幼虫（24時間以内にふ化した個体）で は7.3頭， 1 齢後期（ふ化幼虫をインゲン葉上で24時間 飼育後の個体) で4.1頭であった。ミカンキイロアザミ ウマ，ミナミキイロアザミウマ，ヒラズハナアザミウマ の 1 秢前期幼虫を飭とし，餌密度と捕食量の関係を調杳. した。ミヤコカブリダニの捕食是はいずれのアザミウマ を䬦とした場合も䬣密度が离くなるにつれて增加した。 最大捕食量はミカンキイロアザミウマの塐合7.1頭，ミ ナミキイロアザミウマの場合6.9嗔．ヒラズハナアザミ ウマの場合3.1頭であり，ヒラズハナアザミウマに対す る捕食量はミカンキイロアザミウマ，ミナミキイロアザ ミウマと比べて有意に少なかった。以上の結果から：ミ ヤコカブリダニはミカンキイロアザミウマ，ミナミキイ ロアザミウマの天敵としての利用も期待できると考えら れた。 


\section{引用 文 献}

天野 洋 (2004) ダ二類の天敵 (捕食性ダニ). ミヤコ カブリダニ. 天敵大事典下巻（農文協編）。農文協 (東京) pp. 577-580.

足立年一（2001）捕食性天敵ククメリスカブリダニによ るアザミウマ類の防除。農業㧍よび園芸 $76: 141$ 145.

Friese. D. D. and F. E. Gilstrap (1982) Influence of prey availability on reproduction and prey consumption of Phytoseiulus persimilis, Amblyseius californicus, and Metaseiulus occidentalis (Acarina: Phytoseiidae). Int. J. Acarol. 8 : 85-89.

Holling, C. S. (1959) Some characteristics of simple type of predation and parasitism. Can. Entomol. 91 : 385398.

伊藤嘉昭. 村井実 (1977) 動物生態学研究法 (下). 古 今書院 (東京), pp. 290.

柿元一樹 - 井口拓士 - 井上栄明 - 櫛下町鈈敏 (2004) 子 ザミウマ類に対するニセラーゴカブリダニの捕食能力。 九病出研会報 $50 ： 82$-87.

Lewis, T. (1973) Thrips : Their biology, ecology and economic importance. Academic Press (N.Y.). pp.349.

Maliis, M. and W.J.Ravensberg（1995）天敵利用の基礎 知識. (短野栄二, 和田哲大訳)。農文協 (東京), pp. 116.

森焚須・点梶徳純 (1974) 八ダニ類の生物防除 チリカ
ブリダニの利用を中心として．植物防疫 28：102-106. 斎木陽子（2004）ミヤコカブリダ二剤の使い方．植物防 疫 $58 ： 187-190$.

Shibao Manabu, S. Ehara, A.Hosomi and H. Tanaka (2004) Seasonal fluctuation in population density of phytoseiid mites and the yellow tea thrips, Scirtothrips dorsalis Hood (Thysanoptera : Thripidae) on grape, and predation of the thrips by Euseius sojaensis (Ehara) (Acari : Phytoseiidae). Appl. Entmol. Zool. $39: 727-730$.

Shipp. J. L. and G. H. Whitfield (1991) Functional response of the predatory mite, Amblyseius cucumeris (Acari: Phytoseiidae), on western flower thrips, Frankliniella occidentalis (Thysanoptera:Thripidae) Environ. Entomol. 20: 694-699.

高田裕司・柏尾具俊（2004）カンザワハダニを飭とした 場合のミヤコカブリダニの生物特性とイチゴでの放飼 効果. 九病虫研会報 50：49-54.

嶽本弘之（2003）福岡県における促成栽培イチゴでのチ リカブリダニ，コレマンアブラバチの利用．今月の農 業 47 (11):74-79.

梅津由美子・望月雅俊・矢野栄二（2000）高温条件下に おけるミヤコカブリダニの発育・捕食能力. 北日本病 虫研報 $51: 245-247$ 。

矢野栄二: (2003) 天敵：生態と利用技術, 養賢堂（東 京), pp. 296.

（2005年 4 月30日受領； 7 月29日受理） 